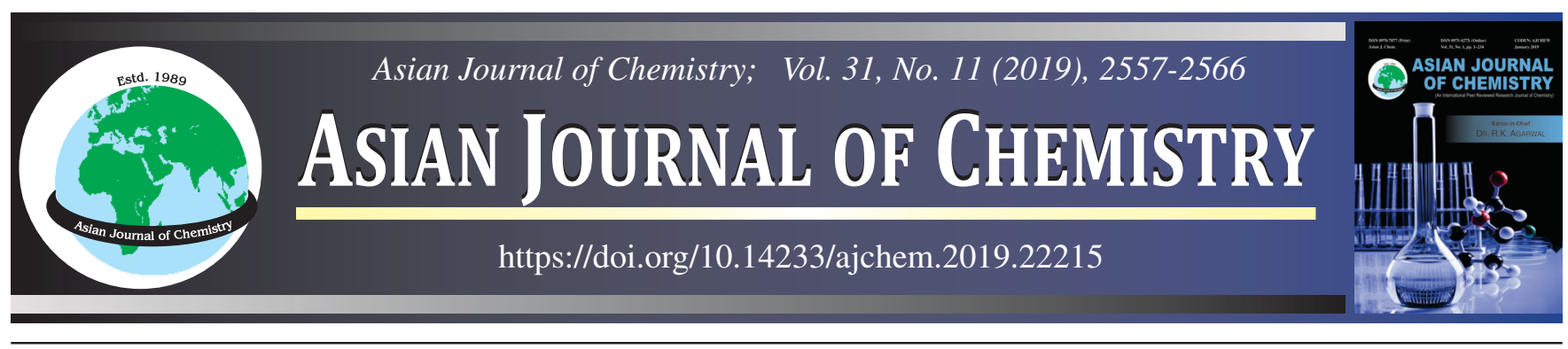

\title{
Viscometric and Conductometric Studies of Doxycycline Hyclate in Water, Aqueous Glycine and L-Alanine Solutions at Different Temperatures
}

\author{
Shashi Kant Sharma*, Poonam and Nisha Sharma
}

Department of Chemistry, Himachal Pradesh University, Summer Hill, Shimla-171005, India

*Corresponding author: E-mail: drsklomesh@ rediffmail.com

Received: 27 May 2019;

Accepted: 19 June 2019;

Published online: 28 September 2019;

AJC-19586

To investigate the behaviour of doxycycline hyclate in water, aqueous glycine and aqueous L-alanine solutions, the viscometric and conductometric studies have been conducted at different temperatures. Viscosity data has been used to derive the Jones-Dole viscosity Bcoefficient, temperature derivative of B-coefficient $(\mathrm{dB} / \mathrm{dT})$, viscosity B-coefficient of transfer $\left(\Delta_{\mathrm{tr}} \mathrm{B}\right)$, free energy of activation of viscous flow per mole of solvent $\left(\Delta \mu_{1}^{0^{*}}\right)$ and solute $\left(\Delta \mu_{2}^{0^{*}}\right)$ respectively, activation entropy $\left(\Delta \mathrm{S}_{2}^{\mathrm{o}^{*}}\right)$ and activation enthalpy $\left(\Delta \mathrm{H}_{2}{ }^{\mathrm{o}^{*}}\right)$. Conductance data has been used to compute Walden product $\left(\Lambda_{\mathrm{m}}^{\circ} \eta_{\mathrm{o}}\right)$ and temperature coefficient of Walden product $\left(\mathrm{d} \Lambda_{\mathrm{m}}^{\circ} \eta_{\mathrm{o}} / \mathrm{dT}\right)$ for doxycycline hyclate in water, and in aqueous glycine and aqueous $\mathrm{L}$-alanine solution. The positive values of B-coefficient, $\Delta_{\mathrm{tr}} \mathrm{B}$ indicate the prevailing of hydrophilicionic interactions in the systems under examination. The negative values of $\mathrm{dB} / \mathrm{dT}$ and positive values of temperature coefficient of Walden product infer structure maker tendency of doxycycline hyclate in water, and in aqueous glycine and aqueous L-alanine solution. Transfer energy parameters indicate the breaking of intermolecular bonds in transition state which means that formation of activated complex is unfavourable.

Keywords: Jones-Dole viscosity, Activation entropy, Activation enthalpy, Walden product.

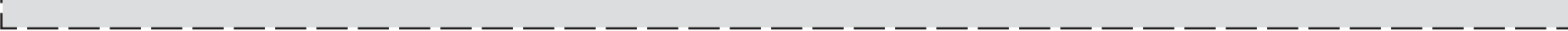

\section{INTRODUCTION}

Proteins are long chains of amino acids which are critically important for catalyzing the chemical reactions, transporting materials across the cell and receiving and sending chemical signals. Proteins are essential for the main physiological processes of life and form essential functions throughout the system of human body. The proteins such as receptors, proteinaceous enzymes, transport proteins, membrane proteins and ion channels serve as the target proteins for most of the drugs in clinical use $[1,2]$. The drug transport and disposition is influenced by drug binding to plasma and tissue proteins. Thus drug- protein binding is one of the most important phenomena during the action of drug. To study the mechanism of the drugprotein molecular interactions, 'amino acids' which are the basic building blocks of proteins and the most important model compound of proteins, are quite appropriate and useful to explore these molecular interactions.

The molecular size, shape, chain length, degree of molecular association and intermolecular interactions has notable effect on viscometric properties of binary/ternary mixtures. Thus, viscometric and conductance study of various bioactive compounds is substantial for understanding the ion-ion, ionhydrophilic and hydrophobic interactions existing in the solutions. The viscometric properties such as viscosity B-coefficient, the viscosity B-coefficient of transfer, free energy of activation of solute/solvent, change in enthalpy and temperature coefficient of Walden product furnish useful information about solute-solute/solute-solvent interactions occurring in solution phase [3-6]. Knowing this advantage, the viscometric measurements have been used in the present study to analyze interactions of drug with water as well as with amino acids. The biochemical processes mostly take place in aqueous media, therefore studying different properties of drugs in aqueous phase will enrich researchers with useful information. This information has significance in industrial and biological fields $[7,8]$. As amino acids are the fundamental structural unit of biological macromolecules mainly proteins [9-11], the results obtained from the above study will also be helpful in understanding the absorption of drugs, transport of drugs across the

This is an open access journal, and articles are distributed under the terms of the Attribution 4.0 International (CC BY 4.0) License. This license lets others distribute, remix, tweak, and build upon your work, even commercially, as long as they credit the author for the original creation. You must give appropriate credit, provide a link to the license, and indicate if changes were made. 
biological membranes, protein hydration, denaturation and aggregation [12-17]. Moreover, to have deeper knowledge of the mechanism of drug action, the viscometric properties could be examined at different temperatures and at variable concentrations of drug and amino acids. In recent years, researchers are developing appreciable interest in studying thermodynamic properties of model compounds like amino acids and small peptides [18-21]. Different attempts have been made by using different techniques to understand interactions taking place between drug and amino acids but little viscometric data is available [22-24].

In present system, the viscometric properties of doxycycline hyclate (drug) in water and aqueous solution of glycine/L-alanine has been studied. Glycine and L-alanine both are non-essential amino acids and are involved in various biochemical processes occurring in the body $[25,26]$. Both the amino acids are amphiprotic in nature as they contain carboxylic acid and amine functional groups thus exist in neutral as well as zwitterionic form in solutions [27]. Side chain of glycine contains single hydrogen atom and that of L-alanine contains methyl group. Different side chains interact differently with the drug molecules which in turn affect the viscometric and conductometric properties. Thus different results are obtained for various viscometric parameters. Since variation in temperature and concentration has significant effect on various type of interactions [25], thus viscometric and conductance measurements have been examined at four different temperatures ( 305.15 to $320.15 \mathrm{~K}$ ) at an interval of $5 \mathrm{~K}$, in order to understand various intermolecular interactions and structure making/breaking ability of the drug in binary/ ternary system (doxycycline hyclate + water and doxycycline hyclate + glycine/L-alanine + water).

\section{EXPERIMENTAL}

Doxycyline hyclate $\left(\mathrm{C}_{22} \mathrm{H}_{24} \mathrm{~N}_{2} \mathrm{O}_{8} \cdot \mathrm{HCl} \cdot 0.5 \mathrm{H}_{2} \mathrm{O} \cdot 0.5 \mathrm{C}_{2} \mathrm{H}_{6} \mathrm{O}\right.$, m.w. $\left.512.94 \mathrm{~g} \mathrm{~mol}^{-1}\right)$, analytical grade, glycine $\left(\mathrm{C}_{2} \mathrm{H}_{5} \mathrm{NO}_{2}\right.$, m.w. $\left.75.07 \mathrm{~g} \mathrm{~mol}^{-1}\right)$ and L-alanine $\left(\mathrm{C}_{3} \mathrm{H}_{7} \mathrm{NO}_{2}\right.$, m.w. $\left.89.09 \mathrm{~g} \mathrm{~mol}^{-1}\right)$ have been used in the present study. After drying the chemicals over anhydrous $\mathrm{CaCl}_{2}$, these have been used as such without any further purification. The mass fraction purity of the used chemicals is $\geq 99 \%$.

In the present work, the doxycycline hyclate has been studied in water, $(0.002,0.004$ and 0.006$) \mathrm{mol} \mathrm{kg}^{-1}$ aqueous glycine and $(0.002,0.004$ and 0.006$) \mathrm{mol} \mathrm{kg}^{-1}$ aqueous L-alanine. The concentration range of doxycycline hyclate that has been examined is (0.002 to 0.01$) \mathrm{mol} \mathrm{kg}^{-1}$ in different solvent systems. For preparing all the solutions the triple distilled water with very low specific conductance has been used and weight measurements have been performed in Shimadzu electronic balance. For viscosity calculations the time of flow has been measured with the jacketed Ostwald viscometer. The density and conductance measurements have been performed using DSA 5000 (Density and Sound Analyzer), Anton Paar and calibrated Digital Conductivity Meter respectively. Both the jacketed viscometer and conductivity meter were connected to water thermostat to maintain the constant temperature. For the calibration of viscometer and density and sound analyzer distilled water was used.

As both, the molality as well as molarity have been used in calculations therefore for converting molality $(\mathrm{m})$ to molarity (C) using the molecular mass (M) of doxycycline hyclate and density $(\rho)$ of solution following relation has been used:

$$
\mathrm{C}=\frac{1000 \mathrm{~m} \rho}{1000+\mathrm{mM}}
$$

In this equation $\mathrm{m}$ is measured in $\mathrm{mol} \mathrm{kg}^{-1}, \mathrm{M}^{\text {in }} \mathrm{g} \mathrm{mol}^{-1}$ and density in $\mathrm{kg} \mathrm{m}^{-3}$.

\section{RESULTS AND DISCUSSION}

Viscometric studies: An attempt has been made to study the behaviour of doxycycline hyclate in water, aqueous glycine and aqueous L-alanine using viscosity parameters. For viscosity calculations following relation has been used [28,29],

$$
\eta_{\mathrm{s}}=\frac{\rho_{\mathrm{s}} \mathrm{t}_{\mathrm{s}} \eta_{\mathrm{o}}}{\rho_{\mathrm{o}} \mathrm{t}_{\mathrm{o}}}
$$

In above equation, $\rho_{\mathrm{s}}\left(\mathrm{kg} \mathrm{m}^{-3}\right)$ is the density, $\mathrm{t}_{\mathrm{s}}(\mathrm{s})$ is flow time of solution and $\eta_{\mathrm{s}}(\mathrm{mPa} \mathrm{s})$ is the viscosity of solution. However, $\rho_{\mathrm{o}}\left(\mathrm{kg} \mathrm{m}^{-3}\right), \mathrm{t}_{\mathrm{o}}(\mathrm{s})$ and $\eta_{\mathrm{o}}(\mathrm{mPa} \mathrm{s})$ are the respective parameters of solvent, respectively. The values of viscosity have been recorded in Table- 1 .

The viscosity is found to increase with the increase in concentration of amino acids as well as drug. This may be due to increase in number of molecules which can participate in interactions as a result there is increase in intermolecular interactions which cause more frictional resistance to the

\begin{tabular}{|c|c|c|c|c|c|c|c|c|}
\hline \multirow{3}{*}{$\begin{array}{c}{ }^{* \mathrm{~m}_{\mathrm{D}}} \\
\left(\mathrm{mol} \mathrm{kg}{ }^{-1}\right)\end{array}$} & \multicolumn{7}{|c|}{$\begin{array}{l}\text { TABLE- } 1 \\
\text { VALUES OF DYNAMIC VISCOSITY }\left(\eta_{\mathrm{s}}\right) \text { AND DENSITY }\left(\rho_{\mathrm{s}}\right) \text { OF DOXYCYCLINE HYCLATE IN } \\
\text { WATER, AQUEOUS GLYCINE AND L-ALANINE AT DIFFERENT TEMPERATURES }\end{array}$} & \\
\hline & \multicolumn{4}{|c|}{$\eta_{\mathrm{s}}(\mathrm{mPa} \mathrm{s})$} & \multicolumn{4}{|c|}{$\rho_{\mathrm{s}} \times 10^{-3}\left(\mathrm{~kg} \mathrm{~m}^{-3}\right)$} \\
\hline & $305.15 \mathrm{~K}$ & $310.15 \mathrm{~K}$ & $315.15 \mathrm{~K}$ & $320.15 \mathrm{~K}$ & $305.15 \mathrm{~K}$ & $310.15 \mathrm{~K}$ & $315.15 \mathrm{~K}$ & $320.15 \mathrm{~K}$ \\
\hline \multicolumn{9}{|c|}{ Doxycycline hyclate + water } \\
\hline 0.000 & 0.7646 & 0.6922 & 0.6302 & 0.5764 & 0.995044 & 0.993310 & 0.991417 & 0.989368 \\
\hline 0.002 & 0.7652 & 0.6928 & 0.6307 & 0.5769 & 0.995312 & 0.993569 & 0.991667 & 0.989610 \\
\hline 0.003 & 0.7654 & 0.6929 & 0.6308 & 0.5770 & 0.995444 & 0.993697 & 0.991791 & 0.989730 \\
\hline 0.004 & 0.7656 & 0.6931 & 0.6310 & 0.5771 & 0.995576 & 0.993824 & 0.991914 & 0.989848 \\
\hline 0.005 & 0.7658 & 0.6932 & 0.6311 & 0.5772 & 0.995706 & 0.993951 & 0.992036 & 0.989966 \\
\hline 0.006 & 0.7659 & 0.6934 & 0.6312 & 0.5773 & 0.995836 & 0.994076 & 0.992157 & 0.990083 \\
\hline 0.007 & 0.7661 & 0.6935 & 0.6314 & 0.5774 & 0.995965 & 0.994201 & 0.992278 & 0.990200 \\
\hline 0.008 & 0.7663 & 0.6937 & 0.6315 & 0.5775 & 0.996093 & 0.994326 & 0.992397 & 0.990316 \\
\hline 0.009 & 0.7665 & 0.6938 & 0.6316 & 0.5776 & 0.996219 & 0.994449 & 0.992516 & 0.990431 \\
\hline 0.010 & 0.7667 & 0.6940 & 0.6318 & 0.5778 & 0.996348 & 0.994572 & 0.992633 & 0.990544 \\
\hline
\end{tabular}
flow of solutions. However, the decrease in viscosity with the 


\begin{tabular}{|c|c|c|c|c|c|c|c|c|}
\hline \multicolumn{9}{|c|}{ Doxycycline hyclate $+0.002 \mathrm{~mol} \mathrm{~kg}^{-1}$ glycine } \\
\hline 0.000 & 0.7702 & 0.6985 & 0.6396 & 0.5863 & 0.995253 & 0.993576 & 0.991672 & 0.989573 \\
\hline 0.002 & 0.7706 & 0.6990 & 0.6400 & 0.5867 & 0.995519 & 0.993835 & 0.991922 & 0.989813 \\
\hline 0.003 & 0.7708 & 0.6991 & 0.6401 & 0.5868 & 0.995653 & 0.993963 & 0.992046 & 0.989932 \\
\hline 0.004 & 0.7710 & 0.6993 & 0.6402 & 0.5869 & 0.995786 & 0.994091 & 0.992168 & 0.990050 \\
\hline 0.005 & 0.7711 & 0.6994 & 0.6403 & 0.5870 & 0.995917 & 0.994218 & 0.992290 & 0.990168 \\
\hline 0.006 & 0.7713 & 0.6995 & 0.6405 & 0.5871 & 0.996047 & 0.994344 & 0.992413 & 0.990286 \\
\hline 0.007 & 0.7715 & 0.6997 & 0.6406 & 0.5872 & 0.996177 & 0.994470 & 0.992534 & 0.990404 \\
\hline 0.008 & 0.7717 & 0.6998 & 0.6407 & 0.5873 & 0.996306 & 0.994595 & 0.992655 & 0.990521 \\
\hline 0.009 & 0.7718 & 0.7000 & 0.6408 & 0.5874 & 0.996435 & 0.994719 & 0.992775 & 0.990636 \\
\hline 0.010 & 0.7720 & 0.7001 & 0.6409 & 0.5875 & 0.996562 & 0.994844 & 0.992895 & 0.990753 \\
\hline \multicolumn{9}{|c|}{ Doxycycline hyclate $+0.004 \mathrm{~mol} \mathrm{~kg}^{-1}$ glycine } \\
\hline 0.000 & 0.7727 & 0.7009 & 0.6418 & 0.5882 & 0.995310 & 0.993625 & 0.991733 & 0.989650 \\
\hline 0.002 & 0.7732 & 0.7013 & 0.6422 & 0.5886 & 0.995576 & 0.993882 & 0.991981 & 0.989888 \\
\hline 0.003 & 0.7733 & 0.7014 & 0.6423 & 0.5887 & 0.995708 & 0.994010 & 0.992104 & 0.990006 \\
\hline 0.004 & 0.7735 & 0.7016 & 0.6424 & 0.5888 & 0.995839 & 0.994137 & 0.992227 & 0.990123 \\
\hline 0.005 & 0.7737 & 0.7017 & 0.6426 & 0.5889 & 0.995969 & 0.994263 & 0.992348 & 0.990240 \\
\hline 0.006 & 0.7738 & 0.7019 & 0.6427 & 0.5890 & 0.996099 & 0.994389 & 0.992469 & 0.990357 \\
\hline 0.007 & 0.7740 & 0.7020 & 0.6428 & 0.5891 & 0.996228 & 0.994513 & 0.992589 & 0.990473 \\
\hline 0.008 & 0.7742 & 0.7022 & 0.6429 & 0.5892 & 0.996356 & 0.994638 & 0.992710 & 0.990589 \\
\hline 0.009 & 0.7743 & 0.7023 & 0.6430 & 0.5893 & 0.996483 & 0.994761 & 0.992828 & 0.990704 \\
\hline 0.010 & 0.7745 & 0.7024 & 0.6431 & 0.5894 & 0.996610 & 0.994884 & 0.992948 & 0.990820 \\
\hline \multicolumn{9}{|c|}{ Doxycycline hyclate $+0.006 \mathrm{~mol} \mathrm{~kg}^{-1}$ glycine } \\
\hline 0.000 & 0.7752 & 0.7030 & 0.6438 & 0.5893 & 0.995439 & 0.993745 & 0.991845 & 0.989720 \\
\hline 0.002 & 0.7757 & 0.7034 & 0.6442 & 0.5897 & 0.995702 & 0.994000 & 0.992090 & 0.989955 \\
\hline 0.003 & 0.7758 & 0.7036 & 0.6443 & 0.5898 & 0.995833 & 0.994126 & 0.992212 & 0.990072 \\
\hline 0.004 & 0.7760 & 0.7037 & 0.6444 & 0.5899 & 0.995963 & 0.994252 & 0.992333 & 0.990189 \\
\hline 0.005 & 0.7762 & 0.7037 & 0.6446 & 0.5900 & 0.996091 & 0.994376 & 0.992453 & 0.990305 \\
\hline 0.006 & 0.7764 & 0.7040 & 0.6447 & 0.5901 & 0.996219 & 0.994500 & 0.992573 & 0.990421 \\
\hline 0.007 & 0.7765 & 0.7041 & 0.6448 & 0.5902 & 0.996347 & 0.994624 & 0.992692 & 0.990536 \\
\hline 0.008 & 0.7767 & 0.7043 & 0.6449 & 0.5903 & 0.996474 & 0.994747 & 0.992810 & 0.990651 \\
\hline 0.009 & 0.7769 & 0.7044 & 0.6450 & 0.5904 & 0.996601 & 0.994870 & 0.992928 & 0.990766 \\
\hline 0.010 & 0.7770 & 0.7046 & 0.6452 & 0.5905 & 0.996727 & 0.994991 & 0.993047 & 0.990880 \\
\hline \multicolumn{9}{|c|}{ Doxycycline hyclate $+0.002 \mathrm{~mol} \mathrm{~kg}^{-1} \mathrm{~L}$-alanine } \\
\hline 0.000 & 0.7727 & 0.7007 & 0.6412 & 0.5880 & 0.995233 & 0.993562 & 0.991646 & 0.989546 \\
\hline 0.002 & 0.7732 & 0.7012 & 0.6416 & 0.5884 & 0.995498 & 0.993819 & 0.991893 & 0.989783 \\
\hline 0.003 & 0.7734 & 0.7013 & 0.6418 & 0.5885 & 0.995630 & 0.993946 & 0.992016 & 0.989901 \\
\hline 0.004 & 0.7736 & 0.7015 & 0.6419 & 0.5886 & 0.995761 & 0.994073 & 0.992138 & 0.990018 \\
\hline 0.005 & 0.7738 & 0.7016 & 0.6420 & 0.5888 & 0.995890 & 0.994199 & 0.992260 & 0.990135 \\
\hline 0.006 & 0.7739 & 0.7018 & 0.6422 & 0.5889 & 0.996020 & 0.994324 & 0.992380 & 0.990253 \\
\hline 0.007 & 0.7741 & 0.7019 & 0.6423 & 0.5890 & 0.996148 & 0.994450 & 0.992501 & 0.990368 \\
\hline 0.008 & 0.7743 & 0.7021 & 0.6424 & 0.5891 & 0.996276 & 0.994575 & 0.992621 & 0.990484 \\
\hline 0.009 & 0.7745 & 0.7022 & 0.6425 & 0.5892 & 0.996403 & 0.994698 & 0.992738 & 0.990601 \\
\hline 0.010 & 0.7747 & 0.7024 & 0.6427 & 0.5893 & 0.996530 & 0.994821 & 0.992858 & 0.990716 \\
\hline \multicolumn{9}{|c|}{ Doxycycline hyclate $+0.004 \mathrm{~mol} \mathrm{~kg}^{-1} \mathrm{~L}$-alanine } \\
\hline 0.000 & 0.7752 & 0.7030 & 0.6431 & 0.5899 & 0.995303 & 0.993608 & 0.991710 & 0.989598 \\
\hline 0.002 & 0.7757 & 0.7035 & 0.6435 & 0.5903 & 0.995567 & 0.993863 & 0.991955 & 0.989833 \\
\hline 0.003 & 0.7759 & 0.7036 & 0.6437 & 0.5904 & 0.995697 & 0.993990 & 0.992077 & 0.989950 \\
\hline 0.004 & 0.7761 & 0.7038 & 0.6438 & 0.5905 & 0.995827 & 0.994115 & 0.992199 & 0.990067 \\
\hline 0.005 & 0.7763 & 0.7039 & 0.6439 & 0.5906 & 0.995956 & 0.994241 & 0.992320 & 0.990183 \\
\hline 0.006 & 0.7764 & 0.7041 & 0.6440 & 0.5907 & 0.996084 & 0.994366 & 0.992439 & 0.990299 \\
\hline 0.007 & 0.7766 & 0.7042 & 0.6442 & 0.5908 & 0.996212 & 0.994490 & 0.992560 & 0.990414 \\
\hline 0.008 & 0.7768 & 0.7044 & 0.6443 & 0.5909 & 0.996338 & 0.994613 & 0.992678 & 0.990529 \\
\hline 0.009 & 0.7770 & 0.7045 & 0.6444 & 0.5911 & 0.996465 & 0.994736 & 0.992797 & 0.990644 \\
\hline 0.010 & 0.7772 & 0.7047 & 0.6446 & 0.5912 & 0.996590 & 0.994858 & 0.992916 & 0.990758 \\
\hline \multicolumn{9}{|c|}{ Doxycycline hyclate $+0.006 \mathrm{~mol} \mathrm{~kg}^{-1} \mathrm{~L}$-alanine } \\
\hline 0.000 & 0.7777 & 0.7053 & 0.6451 & 0.5920 & 0.995370 & 0.993674 & 0.991770 & 0.989685 \\
\hline 0.002 & 0.7782 & 0.7058 & 0.6455 & 0.5924 & 0.995632 & 0.993928 & 0.992014 & 0.989919 \\
\hline 0.003 & 0.7784 & 0.7059 & 0.6456 & 0.5925 & 0.995762 & 0.994053 & 0.992136 & 0.990035 \\
\hline 0.004 & 0.7786 & 0.7061 & 0.6458 & 0.5926 & 0.995891 & 0.994179 & 0.992256 & 0.990151 \\
\hline 0.005 & 0.7787 & 0.7062 & 0.6459 & 0.5927 & 0.996020 & 0.994304 & 0.992377 & 0.990267 \\
\hline 0.006 & 0.7789 & 0.7064 & 0.6460 & 0.5928 & 0.996148 & 0.994428 & 0.992497 & 0.990383 \\
\hline 0.007 & 0.7791 & 0.7066 & 0.6461 & 0.5929 & 0.996274 & 0.994552 & 0.992616 & 0.990497 \\
\hline 0.008 & 0.7793 & 0.7067 & 0.6463 & 0.5930 & 0.996400 & 0.994673 & 0.992734 & 0.990611 \\
\hline 0.009 & 0.7795 & 0.7069 & 0.6464 & 0.5931 & 0.996526 & 0.994793 & 0.992852 & 0.990726 \\
\hline 0.010 & 0.7796 & 0.7070 & 0.6465 & 0.5933 & 0.996651 & 0.994916 & 0.992969 & 0.990840 \\
\hline
\end{tabular}

\footnotetext{
$* \mathrm{~m}_{\mathrm{D}}$ is the molality of doxycycline hyclate in water and in different concentrations of glycine and L-alanine.
} 
increase in temperature may be due to the increase in kinetic energy of molecules present in the solution [30,31].

Jones-Dole equation [32] has been used to examine the variation of $\psi$ with $C^{1 / 2}$ and is represented as:

$$
\psi=\frac{\eta_{\mathrm{r}}-1}{\mathrm{C}^{1 / 2}}=\mathrm{A}+\mathrm{BC}^{1 / 2}
$$

where $\eta_{\mathrm{r}}=\eta_{\mathrm{s}} / \eta_{\mathrm{o}}$ is the relative viscosity of the solution, $\eta_{\mathrm{s}}$ and $\eta_{\mathrm{o}}$ are the viscosities of solution and solvent respectively and
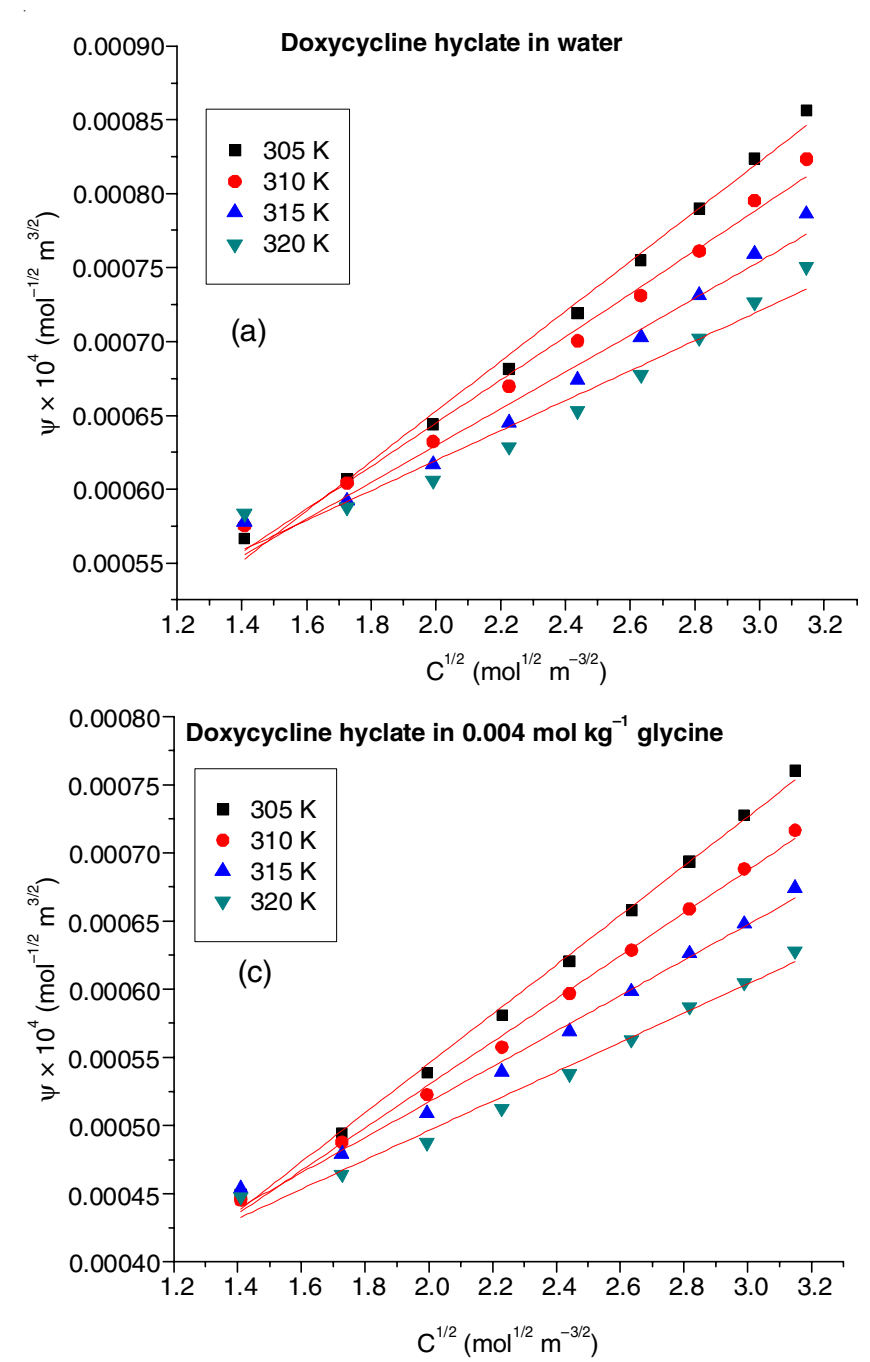

$\mathrm{C}$ is the molarity $\left(\mathrm{mol} \mathrm{m}^{-3}\right)$ of the solution. Figs. 1 and 2 give the graphical representation of eqn. 3 .

The intercept A is called Falkenhagen coefficient which is an indicative of solute-solute interactions and slope B is called Jones-Dole coefficient which measures solute-solvent interactions $[32,33]$. The values of $\left(\eta_{\mathrm{r}}-1\right) / \mathrm{C}^{1 / 2}$ are listed in Table-2. The larger positive values of $\mathrm{B}$ than $\mathrm{A}$ indicates that solute-solvent interactions are stronger than solute-solute interactions in all the systems under consideration [34]. This
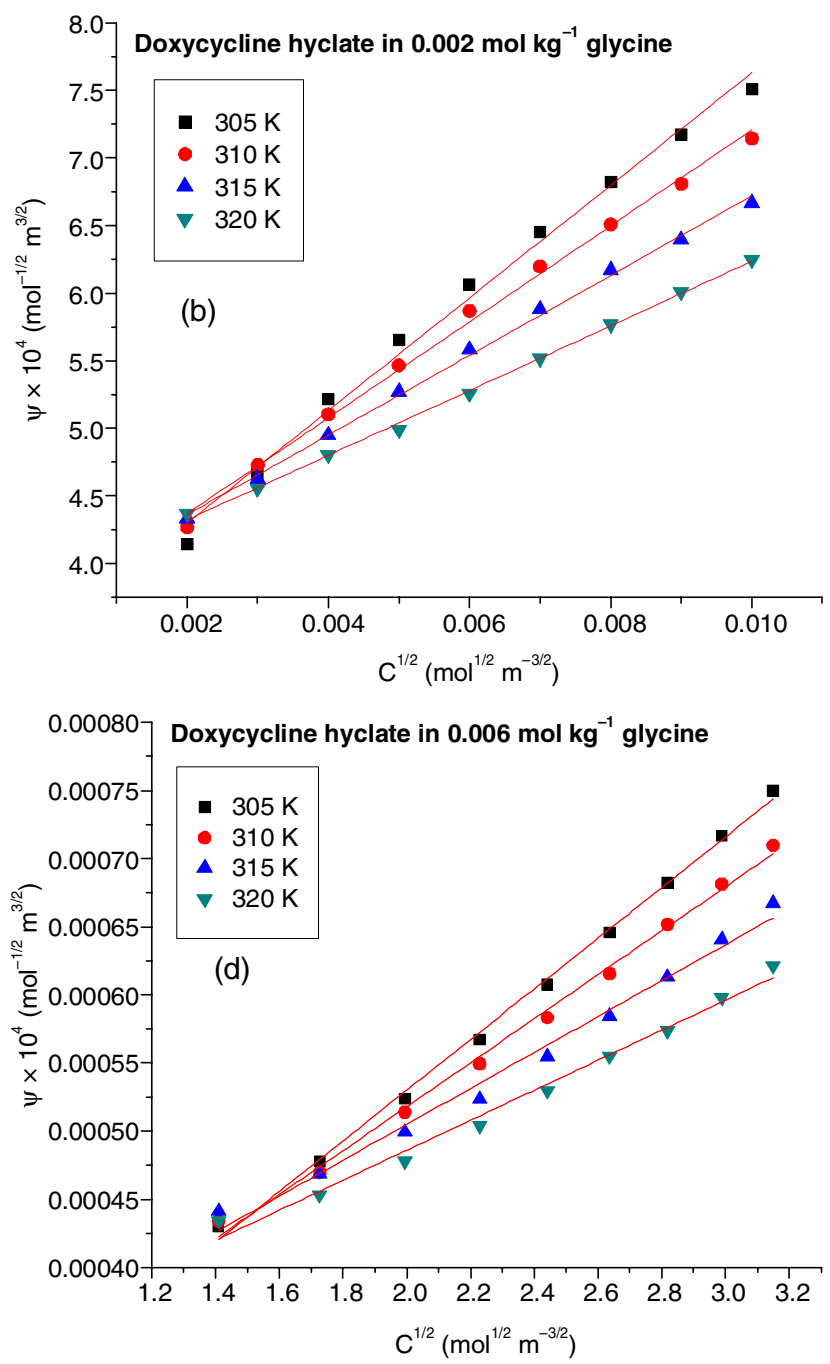

Fig. 1. Plots of $\psi=\left(\eta_{\mathrm{r}}-1\right) / \mathrm{C}^{1 / 2} v s$. concentration $\left(\mathrm{C}^{1 / 2}\right)$ for doxycycline hyclate in (a) water (b) $0.002 \mathrm{~mol} \mathrm{~kg}^{-1}$ aqueous glycine (c) $0.004 \mathrm{~mol}$ $\mathrm{kg}^{-1}$ aqueous glycine (d) $0.006 \mathrm{~mol} \mathrm{~kg}^{-1}$ aqueous glycine at different temperatures
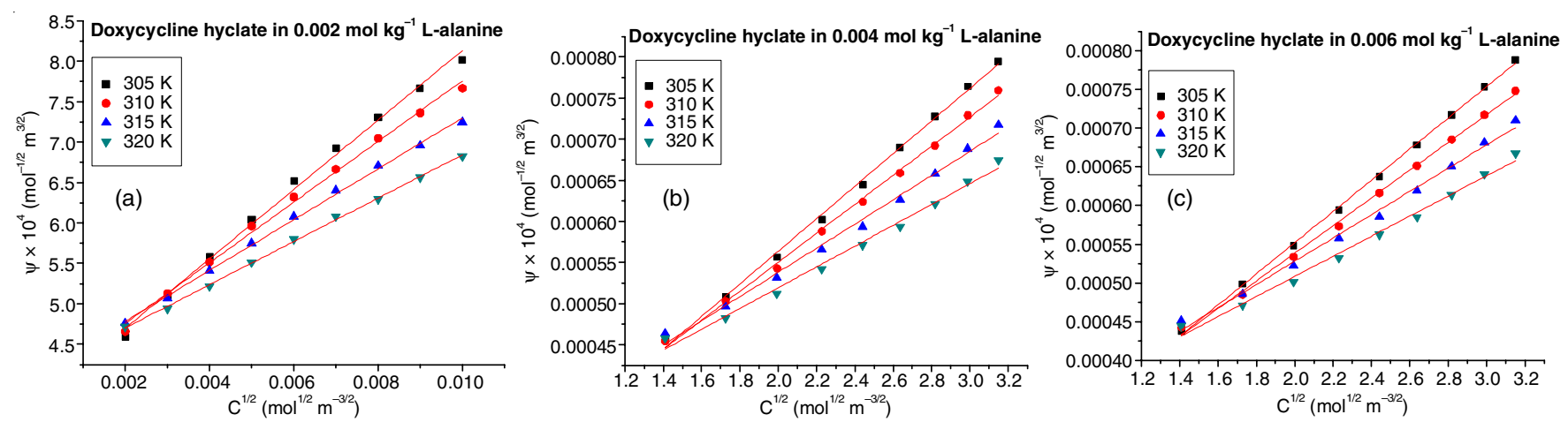

Fig. 2. Plots of $\psi=\left(\eta_{\mathrm{r}}-1\right) / \mathrm{C}^{1 / 2}$ vs. concentration $\left(\mathrm{C}^{1 / 2}\right)$ for doxycycline hyclate in (a) $0.002 \mathrm{~mol} \mathrm{~kg}^{-1}$ aqueous alanine (b) $0.004 \mathrm{~mol} \mathrm{~kg}{ }^{-1}$ aqueous alanine (c) $0.006 \mathrm{~mol} \mathrm{~kg}^{-1}$ aqueous alanine at different temperatures 


\begin{tabular}{|c|c|c|c|c|c|c|c|c|}
\hline \multirow{3}{*}{$\begin{array}{c}{ }^{* \mathrm{~m}_{\mathrm{D}}} \\
\left(\mathrm{mol} \mathrm{kg} \mathrm{kg}^{-1}\right)\end{array}$} & \multicolumn{7}{|c|}{$\begin{array}{c}\text { TABLE-2 } \\
\text { VALUES OF } \psi=\left(\eta_{\mathrm{r}}-1\right) / \mathrm{C}^{1 / 2}\left(\times 10^{4} \mathrm{~mol}^{-1 / 2} \mathrm{~m}^{3 / 2}\right) \text { OF DOXYCYCLINE HYCLATE IN WATER AND } \\
\text { AQUEOUS SOLUTIONS OF GLYCINE AND L-ALANINE AT DIFFERENT TEMPERATURES }\end{array}$} & \multirow[b]{2}{*}{$320.15 \mathrm{~K}$} \\
\hline & $305.15 \mathrm{~K}$ & $310.15 \mathrm{~K}$ & $315.15 \mathrm{~K}$ & $320.15 \mathrm{~K}$ & $305.15 \mathrm{~K}$ & $310.15 \mathrm{~K}$ & $315.15 \mathrm{~K}$ & \\
\hline & \multicolumn{4}{|c|}{ Doxycycline hyclate + water } & \multicolumn{4}{|c|}{ Doxycycline hyclate $+0.002 \mathrm{~mol} \mathrm{~kg}^{-1}$ glycine } \\
\hline 0.002 & 5.6638 & 5.7527 & 5.7754 & 5.8338 & 4.1429 & 4.2669 & 4.3314 & 4.3663 \\
\hline 0.003 & 6.0660 & 6.0402 & 5.9187 & 5.8792 & 4.6615 & 4.7290 & 4.6257 & 4.5563 \\
\hline 0.004 & 6.4365 & 6.3220 & 6.1681 & 6.0584 & 5.2165 & 5.1023 & 4.9495 & 4.8046 \\
\hline 0.005 & 6.8157 & 6.6957 & 6.4496 & 6.2839 & 5.6513 & 5.4646 & 5.2712 & 4.9890 \\
\hline 0.006 & 7.1887 & 7.0038 & 6.7394 & 6.5264 & 6.0642 & 5.8699 & 5.5829 & 5.2560 \\
\hline 0.007 & 7.5509 & 7.3099 & 7.0284 & 6.7740 & 6.4528 & 6.1965 & 5.8829 & 5.5160 \\
\hline 0.008 & 7.9011 & 7.6105 & 7.3126 & 7.0212 & 6.8206 & 6.5094 & 6.1712 & 5.7679 \\
\hline 0.009 & 8.2396 & 7.9525 & 7.5907 & 7.2654 & 7.1705 & 6.8097 & 6.3960 & 6.0116 \\
\hline \multirow[t]{2}{*}{0.010} & 8.5668 & 8.2360 & 7.8619 & 7.5055 & 7.5049 & 7.1440 & 6.6660 & 6.2475 \\
\hline & \multicolumn{4}{|c|}{ Doxycycline hyclate $+0.004 \mathrm{~mol} \mathrm{~kg}^{-1}$ glycine } & \multicolumn{4}{|c|}{ Doxycycline hyclate $+0.006 \mathrm{~mol} \mathrm{~kg}^{-1}$ glycine } \\
\hline 0.002 & 4.4965 & 4.4552 & 4.5379 & 4.4730 & 4.2986 & 4.3404 & 4.4131 & 4.3438 \\
\hline 0.003 & 4.9461 & 4.8787 & 4.7905 & 4.6402 & 4.7802 & 4.6986 & 4.6851 & 4.5327 \\
\hline 0.004 & 5.3878 & 5.2287 & 5.0891 & 4.8745 & 5.2404 & 5.1410 & 4.9948 & 4.7798 \\
\hline 0.005 & 5.8071 & 5.5746 & 5.3932 & 5.1258 & 5.6720 & 5.4934 & 5.2363 & 5.0396 \\
\hline 0.006 & 6.2035 & 5.9674 & 5.6916 & 5.3786 & 6.0771 & 5.8322 & 5.5460 & 5.2986 \\
\hline 0.007 & 6.5791 & 6.2843 & 5.9811 & 5.6274 & 6.4593 & 6.1567 & 5.8439 & 5.5521 \\
\hline 0.008 & 6.9363 & 6.5892 & 6.2607 & 5.8702 & 6.8216 & 6.5181 & 6.1303 & 5.7381 \\
\hline 0.009 & 7.2772 & 6.8827 & 6.4785 & 6.0492 & 7.1666 & 6.8136 & 6.4058 & 5.9806 \\
\hline \multirow[t]{2}{*}{0.010} & 7.6038 & 7.1657 & 6.7422 & 6.2814 & 7.4965 & 7.0982 & 6.6713 & 6.2153 \\
\hline & \multicolumn{4}{|c|}{ Doxycycline hyclate $+0.002 \mathrm{~mol} \mathrm{~kg}^{-1}$ alanine } & \multicolumn{4}{|c|}{ Doxycycline hyclate $+0.004 \mathrm{~mol} \mathrm{~kg}^{-1}$ alanine } \\
\hline 0.002 & 4.5882 & 4.6589 & 4.7637 & 4.7163 & 4.5732 & 4.5425 & 4.6391 & 4.5806 \\
\hline 0.003 & 5.0959 & 5.1280 & 5.0664 & 4.9380 & 5.0792 & 5.0286 & 4.9612 & 4.8237 \\
\hline 0.004 & 5.5824 & 5.5165 & 5.4073 & 5.2182 & 5.5642 & 5.4269 & 5.3131 & 5.1162 \\
\hline 0.005 & 6.0392 & 5.9605 & 5.7487 & 5.5101 & 6.0196 & 5.8769 & 5.6618 & 5.4161 \\
\hline 0.006 & 6.5215 & 6.3200 & 6.0810 & 5.7996 & 6.4474 & 6.2408 & 5.9353 & 5.7113 \\
\hline 0.007 & 6.9226 & 6.6652 & 6.4016 & 6.0822 & 6.9001 & 6.5891 & 6.2644 & 5.9337 \\
\hline 0.008 & 7.3036 & 7.0471 & 6.7102 & 6.2959 & 7.2798 & 6.9227 & 6.5797 & 6.2153 \\
\hline 0.009 & 7.6669 & 7.3624 & 6.9553 & 6.5649 & 7.6419 & 7.2905 & 6.8825 & 6.4869 \\
\hline \multirow[t]{2}{*}{0.010} & 8.0146 & 7.6664 & 7.2447 & 6.8251 & 7.9476 & 7.5959 & 7.1737 & 6.7492 \\
\hline & \multicolumn{4}{|c|}{ Doxycycline hyclate $+0.006 \mathrm{~mol} \mathrm{~kg}^{-1}$ alanine } & & & & \\
\hline 0.002 & 4.3761 & 4.4267 & 4.5145 & 4.4441 & & & & \\
\hline 0.003 & 4.9884 & 4.8475 & 4.8558 & 4.7083 & & & & \\
\hline 0.004 & 5.4817 & 5.3376 & 5.2186 & 5.0129 & & & & \\
\hline 0.005 & 5.9424 & 5.7300 & 5.5745 & 5.3206 & & & & \\
\hline 0.006 & 6.3739 & 6.1619 & 5.8532 & 5.6214 & & & & \\
\hline 0.007 & 6.7802 & 6.5133 & 6.1860 & 5.8481 & & & & \\
\hline 0.008 & 7.1650 & 6.8493 & 6.5041 & 6.1329 & & & & \\
\hline 0.009 & 7.5311 & 7.1712 & 6.8091 & 6.4070 & & & & \\
\hline 0.010 & 7.8811 & 7.4804 & 7.1021 & 6.6712 & & & & \\
\hline
\end{tabular}

$* \mathrm{~m}_{\mathrm{D}}$ is the molality of doxycycline hyclate in water and in different concentrations of glycine and L-alanine.

further indicates the presence kosmotropes i.e. strongly hydrated solutes in solutions and prevailing of hydrophilicionic interactions. It is observed that the magnitude of Bcoefficient decrease in the order, L-alanine $>$ glycine $>$ water which indicates that the hydrophilic-ionic interactions are more effective in aqueous glycine/L-alanine solutions than in water. This may be due to the presence of zwitter ionic group in glycine/ L-alanine which interacts with charged groups of doxycycline hyclate. The variation of B-coefficient with temperature (T) has been shown in Fig. 3.

The sign of temperature derivative of $\mathrm{B}$ i.e. $\mathrm{dB} / \mathrm{dT}$ gives important information about structure making and structure breaking ability of solute in different solvent systems. The negative values of $\mathrm{dB} / \mathrm{dT}$ in the present system indicate structure making behaviour of doxycycline hyclate in water as well as in aqueous solutions of glycine/L-alanine. Similar results have been obtained by Kaur and Kumar [31] in their study of L-serine in ampicillin and amoxicillin.

Further, viscosity B-coefficient values have also been used to obtain the viscosity B-coefficient of transfer $\left(\Delta_{\mathrm{tr}} \mathrm{B}\right)$ from water to aqueous glycine/L-alanine solution and for calculations following equation has been used $[35,36]$ :

$$
\Delta_{\mathrm{tr}} \mathrm{B}=\mathrm{B} \text { (aq. glycine/L-alanine) }-\mathrm{B} \text { (water) }
$$

The values of B-coefficient and $\mathrm{dB} / \mathrm{dT}$ along with the values of $\Delta_{\mathrm{t}} \mathrm{B}$ have been reported in Table-3.

It is revealed from the positive values of $\Delta_{\mathrm{t}} \mathrm{B}$ that hydrophilicionic interactions are more operative than the hydrophobicionic interactions in aqueous glycine and L-alanine. The positive values also indicate that structural order in solution is enhanced in the presence of glycine and L-alanine which may be due to more productive hydrophilic-ionic interactions 

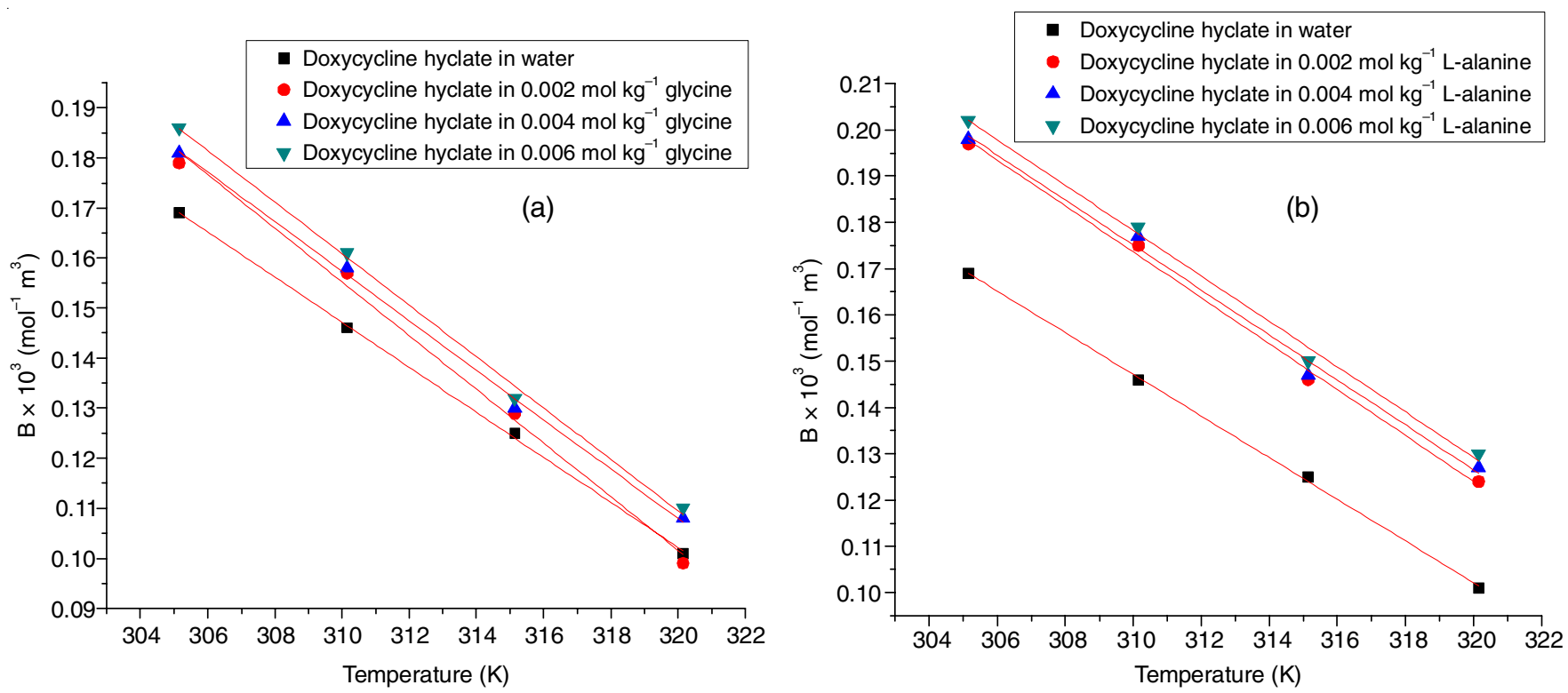

Fig. 3. Plots of B-coefficient $v s$. temperature (T) for doxycycline hyclate in (a) water and $(0.002,0.004$ and 0.006$) \mathrm{mol} \mathrm{kg}^{-1}$ aqueous glycine (b) water and $(0.002,0.004$ and 0.006$) \mathrm{mol} \mathrm{kg}^{-1}$ aqueous L-alanine

TABLE-3

VALUES OF B-COEFFICIENT, $\Delta_{t \mathrm{r}} \mathrm{B}$ AND dB/dT OF DOXYCYCLINE HYCLATE IN WATER, AQUEOUS GLYCINE AND L-ALANINE

\begin{tabular}{|c|c|c|c|c|c|c|c|}
\hline \multirow{2}{*}{$\begin{array}{l}\text { Temperature } \\
\text { (K) }\end{array}$} & \multirow{2}{*}{$\begin{array}{c}\text { Doxycycline } \\
\text { hyclate in water }\end{array}$} & \multicolumn{3}{|c|}{ Doxycycline hyclate in aqueous glycine } & \multicolumn{3}{|c|}{ Doxycycline hyclate in aqueous L-alanine } \\
\hline & & $0.002 \mathrm{~mol} \mathrm{~kg}^{-1}$ & $0.004 \mathrm{~kg}^{-1} \mathrm{~mol}$ & $0.006 \mathrm{~mol} \mathrm{~kg}^{-1}$ & $0.002 \mathrm{~mol} \mathrm{~kg}^{-1}$ & $0.004 \mathrm{~mol} \mathrm{~kg}^{-1}$ & $0.006 \mathrm{~mol} \mathrm{~kg}^{-1}$ \\
\hline \multicolumn{8}{|c|}{$\mathrm{B} \times 10^{3}\left(\mathrm{~mol}^{-1} \mathrm{~m}^{3}\right)$} \\
\hline 305.15 & 0.169 & 0.179 & 0.181 & 0.186 & 0.197 & 0.198 & 0.202 \\
\hline 310.15 & 0.146 & 0.157 & 0.158 & 0.161 & 0.175 & 0.177 & 0.179 \\
\hline 315.15 & 0.125 & 0.129 & 0.130 & 0.132 & 0.146 & 0.147 & 0.150 \\
\hline 320.15 & 0.101 & 0.099 & 0.108 & 0.110 & 0.124 & 0.127 & 0.130 \\
\hline \multicolumn{8}{|c|}{$\Delta_{\mathrm{tr}} \mathrm{B} \times 10^{3}\left(\mathrm{~mol}^{-1} \mathrm{~m}^{3}\right)$} \\
\hline 305.15 & - & 0.010 & 0.012 & 0.017 & 0.028 & 0.029 & 0.032 \\
\hline 310.15 & - & 0.011 & 0.012 & 0.016 & 0.029 & 0.031 & 0.033 \\
\hline 315.15 & - & 0.004 & 0.005 & 0.007 & 0.021 & 0.023 & 0.025 \\
\hline 320.15 & - & 0.002 & 0.007 & 0.009 & 0.023 & 0.025 & 0.028 \\
\hline \multicolumn{8}{|c|}{$\mathrm{dB} / \mathrm{dT} \times 10^{3}\left(\mathrm{~mol}^{-1} \mathrm{~m}^{3} \mathrm{~K}^{-1}\right)$} \\
\hline & -0.005 & -0.005 & -0.005 & -0.005 & -0.005 & -0.005 & -0.005 \\
\hline
\end{tabular}

between zwitter ions of glycine/L-alanine and charged groups of drug. The higher values of $\Delta_{\mathrm{tr}} \mathrm{B}$ in aqueous solution of Lalanine than glycine indicate that hydrophilic-ionic interactions are more pronounced in aqueous solution of L-alanine due to effective interactions between zwitter ionic centre of L-alanine and charged groups of drug. However, due to the small size of glycine, it occupies the cages formed by water molecules and is not easily available for interactions with doxycycline hyclate.

Thermodynamic activation parameters of viscous flow: The thermodynamic activation parameters of viscous flow consist of $\Delta \mu_{1}{ }^{{ }^{*}}$ and $\Delta \mu_{2}^{o^{*}}$ i.e. free energy of activation of viscous flow per mole of solvent and free energy of activation of viscous flow per mole of solute respectively.

Eyring and coworkers [37] gave an equation to calculate and after rearrangement it is written as:

$$
\Delta \mu_{1}^{\mathrm{o}^{*}}=\mathrm{RT} \ln \left(\frac{\eta_{\mathrm{o}} \mathrm{V}_{1}^{\mathrm{o}}}{\mathrm{hN_{ \textrm {A } }}}\right)
$$

In this equation, $h$ is the Planck's constant, $\mathrm{N}_{\mathrm{A}}$ is Avogadro's number, $\mathrm{R}$ is the universal gas constant, $\mathrm{T}$ is the temperature and $\mathrm{V}_{1}^{\mathrm{o}}\left(=\Sigma \mathrm{x}_{\mathrm{i}} \mathrm{M}_{\mathrm{i}} / \mathrm{d}\right)$ is the partial molar volume of the solvent. In the expression $\mathrm{V}_{1}^{\mathrm{o}}=\Sigma \mathrm{x}_{\mathrm{i}} \mathrm{M}_{\mathrm{i}} / \mathrm{d}, \mathrm{x}_{\mathrm{i}}$ is the mole fraction of solvent mixture, $\mathrm{M}_{\mathrm{i}}$ is the molecular weight of solvent mixture, $\mathrm{d}$ is the density of solvent mixture.

Similarly Feakins et al. [29,38] used Eyring transition state theory [39] gave an expression to calculate $\Delta \mu_{2}^{\mathrm{o}^{*}}$ :

$$
\Delta \mu_{2}^{\mathrm{o}^{*}}=\Delta \mu_{1}^{\mathrm{o}^{*}}+\left[\left(\mathrm{B}-\left(\mathrm{V}_{1}^{\mathrm{o}}-\mathrm{V}_{2}^{\mathrm{o}}\right)\left(\mathrm{RT} / \mathrm{V}_{1}^{\mathrm{o}}\right)\right.\right.
$$

In this equation $\mathrm{V}_{2}^{\mathrm{o}}=\mathrm{V}_{\phi}^{\mathrm{o}}$ and the values of $\mathrm{V}_{1}^{\circ}, \mathrm{V}_{2}{ }^{\circ}, \Delta \mu_{1}{ }^{{ }^{* *}}$ and $\Delta \mu_{2}^{\mathrm{o}^{*}}$ are reported in Table-4.

The positive and larger values of $\Delta \mu_{2}^{0^{*}}$ over $\Delta \mu_{1}{ }^{*^{*}}$ indicate that the hydrophilic-ionic interactions persisting in the different solutions are more effective in ground state than in the transition state. The $\Delta \mu_{2}^{0^{*}}$ values are found to be larger in aqueous solution of amino acids than in water which may be due to more operative hydrophilic-ionic interactions between zwitter ions of amino acids and charged groups of drug. The comparative studies has also shown that the values of $\Delta \mu_{2}^{0^{* *}}$ are larger in aqueous L-alanine than in aqueous glycine which indicates the effective hydrophilic-ionic interactions in in aqueous L-alanine. This is due to more effective ion-hydrophilic inter- 
TABLE-4

VALUES OF $\mathrm{V}_{1}^{\mathrm{o}}, \mathrm{V}_{2}^{\mathrm{o}}, \Delta \mu_{1}^{\mathrm{o}^{*}}, \Delta \mu_{2}^{\mathrm{o}^{*}}, \mathrm{~T} \Delta \mathrm{S}_{2}^{\mathrm{0}^{*}}$ AND $\Delta \mathrm{H}_{2}^{\mathrm{o}^{*}}$ OF DOXYCYCLINE HYCLATE IN WATER, AQUEOUS GLYCINE AND L-ALANINE AT DIFFERENT TEMPERATURES

\begin{tabular}{|c|c|c|c|c|c|c|}
\hline Temperature $(\mathrm{K})$ & $\mathrm{V}_{1}^{0} \times 10^{6}\left(\mathrm{~m}^{3} \mathrm{~mol}^{-1}\right)$ & $\mathrm{V}_{2}^{\mathrm{o}} \times 10^{6}\left(\mathrm{~m}^{3} \mathrm{~mol}^{-1}\right)$ & $\Delta \mu_{1}^{\mathrm{o}^{*}}\left(\mathrm{~kJ} \mathrm{~mol}^{-1}\right)$ & $\Delta \mu_{2}^{\mathrm{o}^{*}}\left(\mathrm{~kJ} \mathrm{~mol}^{-1}\right)$ & $\mathrm{T} \Delta \mathrm{S}_{2}^{\mathrm{o}^{*}}\left(\mathrm{~kJ} \mathrm{~mol}{ }^{-1}\right)$ & $\Delta \mathrm{H}_{2}^{\mathrm{o}^{*}}\left(\mathrm{~kJ} \mathrm{~mol}^{-1}\right)$ \\
\hline \multicolumn{7}{|c|}{ Doxycycline hyclate + water } \\
\hline 305.15 & 18.130 & 379.721 & 9.001 & 83.263 & 112.600 & 195.863 \\
\hline 310.15 & 18.189 & 384.271 & 8.901 & 81.475 & 114.445 & 195.920 \\
\hline 315.15 & 18.321 & 389.136 & 8.817 & 79.704 & 116.290 & 195.994 \\
\hline 320.15 & 18.413 & 394.084 & 8.733 & 77.698 & 118.135 & 195.833 \\
\hline \multicolumn{7}{|c|}{ Doxycycline hyclate $+0.002 \mathrm{~mol} \mathrm{~kg}^{-1}$ glycine } \\
\hline 305.15 & 18.086 & 379.970 & 9.013 & 87.102 & 142.505 & 229.607 \\
\hline 310.15 & 18.116 & 384.483 & 8.914 & 84.623 & 144.840 & 229.463 \\
\hline 315.15 & 18.151 & 389.629 & 8.831 & 82.279 & 147.175 & 229.454 \\
\hline 320.15 & 18.190 & 395.451 & 8.746 & 80.105 & 149.510 & 229.615 \\
\hline \multicolumn{7}{|c|}{ Doxycycline hyclate $+0.004 \mathrm{~mol} \mathrm{~kg}^{-1}$ glycine } \\
\hline 305.15 & 18.085 & 380.331 & 9.021 & 85.228 & 111.685 & 196.913 \\
\hline 310.15 & 18.115 & 385.278 & 8.922 & 83.624 & 113.515 & 197.139 \\
\hline 315.15 & 18.150 & 390.467 & 8.840 & 81.383 & 115.345 & 196.728 \\
\hline 320.15 & 18.188 & 396.441 & 8.754 & 79.875 & 117.175 & 197.050 \\
\hline \multicolumn{7}{|c|}{ Doxycycline hyclate $+0.006 \mathrm{~mol} \mathrm{~kg}^{-1}$ glycine } \\
\hline 305.15 & 18.082 & 381.795 & 9.029 & 86.138 & 119.314 & 205.452 \\
\hline 310.15 & 18.113 & 386.458 & 8.930 & 84.352 & 121.269 & 205.621 \\
\hline 315.15 & 18.148 & 391.941 & 8.848 & 81.853 & 123.224 & 205.077 \\
\hline 320.15 & 18.187 & 397.865 & 8.759 & 80.450 & 125.179 & 205.629 \\
\hline \multicolumn{7}{|c|}{ Doxycycline hyclate $+0.002 \mathrm{~mol} \mathrm{~kg}^{-1} \mathrm{~L}$-alanine } \\
\hline 305.15 & 18.086 & 380.768 & 9.022 & 87.987 & 118.093 & 206.080 \\
\hline 310.15 & 18.117 & 385.592 & 8.922 & 86.118 & 120.028 & 206.146 \\
\hline 315.15 & 18.152 & 390.956 & 8.838 & 83.743 & 121.963 & 205.706 \\
\hline 320.15 & 18.190 & 397.005 & 8.753 & 82.335 & 123.898 & 206.233 \\
\hline \multicolumn{7}{|c|}{ Doxycycline hyclate $+0.004 \mathrm{~mol} \mathrm{~kg}^{-1} \mathrm{~L}$-alanine } \\
\hline 305.15 & 18.085 & 381.479 & 9.030 & 87.832 & 105.582 & 193.414 \\
\hline 310.15 & 18.116 & 386.423 & 8.930 & 86.485 & 107.312 & 193.797 \\
\hline 315.15 & 18.151 & 392.026 & 8.846 & 84.095 & 109.042 & 193.137 \\
\hline 320.15 & 18.189 & 397.899 & 8.762 & 82.864 & 110.772 & 193.636 \\
\hline \multicolumn{7}{|c|}{ Doxycycline hyclate $+0.006 \mathrm{~mol} \mathrm{~kg}^{-1} \mathrm{~L}$-alanine } \\
\hline 305.15 & 18.084 & 382.352 & 9.038 & 88.410 & 104.666 & 193.077 \\
\hline 310.15 & 18.116 & 386.423 & 8.939 & 86.836 & 106.381 & 193.218 \\
\hline 315.15 & 18.149 & 392.383 & 8.854 & 84.575 & 108.096 & 192.672 \\
\hline 320.15 & 18.188 & 398.581 & 8.771 & 83.441 & 109.811 & 193.253 \\
\hline
\end{tabular}

actions between zwitter ionic centres of L-alanine and charged groups of drug in aqueous solution of L-alanine than in aqueous solution of glycine as explained earlier. However the increasing trend in $\Delta \mu_{2}^{0^{*}}$ values with the rise in concentration of amino acids indicates increase in solute-solvent interactions. The large positive values of $\Delta \mu_{2}^{\mathrm{o}^{*}}$ also suggest structure maker tendency of doxycycline hyclate in different solvent systems.

The activation entropy $\left(\Delta \mathrm{S}_{2}^{\circ *}\right)$ can be derived from the following relation:

$$
\frac{\mathrm{d}\left(\Delta \mu_{2}^{\mathrm{o}^{*}}\right)}{\mathrm{dT}}=-\Delta \mathrm{S}_{2}^{\mathrm{o}^{*}}
$$

This is the expression for slope of linear plots of $\Delta \mathrm{S}_{2}^{0^{*}} v s$. $\mathrm{T}$ as shown in Fig. 4.

The activation enthalpy $\left(\Delta \mathrm{H}_{2}^{\mathrm{o}^{*}}\right)$ for viscous flow of doxycycline hyclate has also been calculated using the following relation:

$$
\Delta \mu_{2}^{\mathrm{o}^{*}}=\Delta \mathrm{H}_{2}^{\mathrm{o}^{*}}+\mathrm{T} \Delta \mathrm{S}_{2}^{\mathrm{o}^{*}}
$$

The values of $\mathrm{T} \Delta \mathrm{S}_{2}^{\mathrm{o}^{*}}$ and $\Delta \mathrm{H}_{2}^{0^{* *}}$ at different temperatures have been reported in Table- 4 .
The positive values of $\mathrm{T} \Delta \mathrm{S}_{2}^{\mathrm{o}^{*}}$ for all the experimental solutions at all temperatures suggest that transition state is very disordered and the positive $\Delta \mathrm{H}_{2}^{\mathrm{O}^{*}}$ values indicate that bond breaking takes place in transition state and therefore formation of activated complex is unfavourable. The comparative studies has also shown that more energy is required for the formation of transition state in aqueous L-alanine than in aqueous glycine which may be due to stronger hydrophilic-ionic interactions in aqueous L-alanine than in aqueous glycine.

\section{Conductance studies (Walden product)}

The specific conductance $(\kappa)$ and molar concentration $(C)$ of examined dilute solutions has been used to calculate the molar conductance $\left(\Lambda_{\mathrm{m}}\right)$ by using following relation:

$$
\Lambda_{\mathrm{m}}=\frac{\kappa \times 1000}{\mathrm{C}}
$$

The values of $\Lambda_{\mathrm{m}}$ are reported in Table-5.

Onsager equation has been used to study the relation between $\Lambda_{\mathrm{m}}$ and $\mathrm{C}^{1 / 2}$. This equation is given as:

$$
\Lambda_{\mathrm{m}}=\Lambda_{\mathrm{m}}^{\circ}-\mathrm{KC}^{1 / 2}
$$



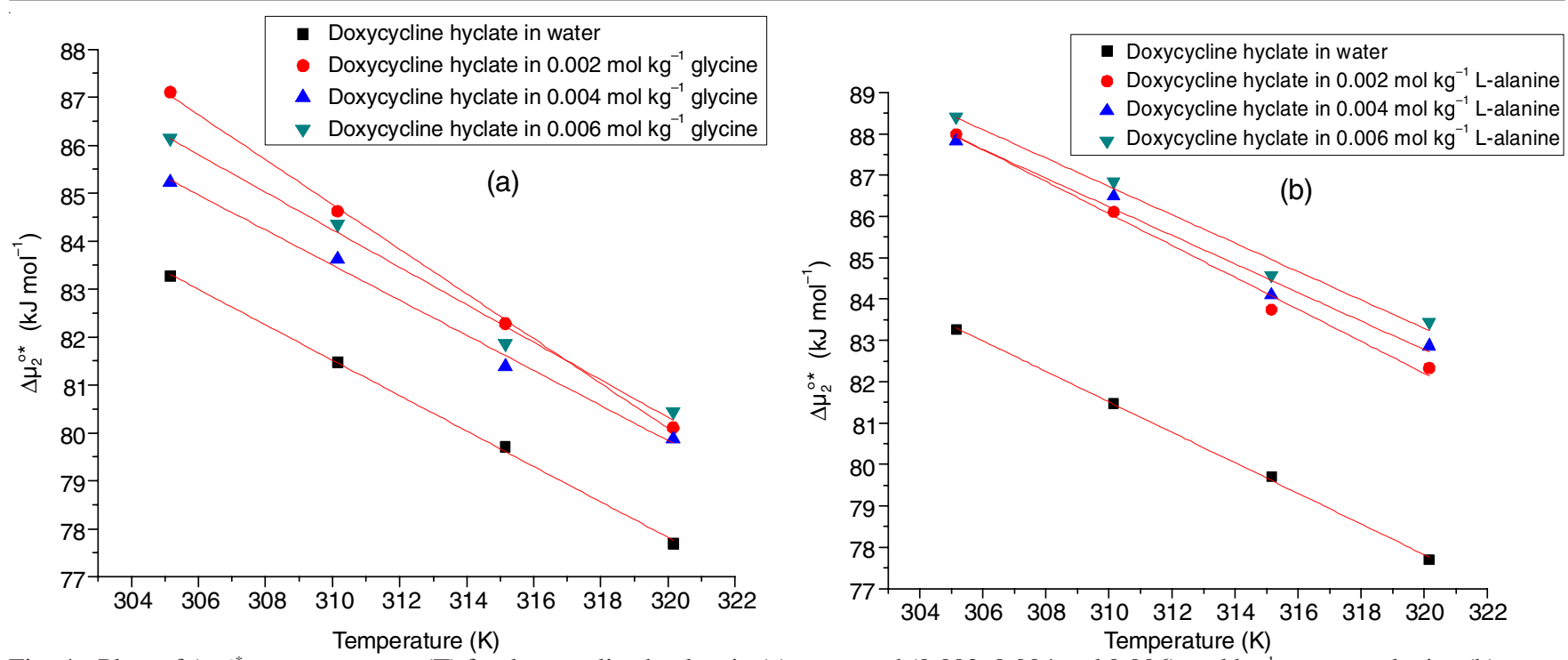

Fig. 4. Plots of $\Delta \mu_{2}{ }^{{ }^{*}} v s$. temperature (T) for doxycycline hyclate in (a) water and $(0.002,0.004$ and 0.006$) \mathrm{mol} \mathrm{kg}^{-1}$ aqueous glycine (b) water and $(0.002,0.004$ and 0.006$) \mathrm{mol} \mathrm{kg}^{-1}$ aqueous L-alanine

TABLE-5

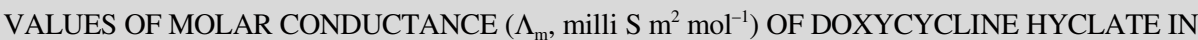
WATER, AQUEOUS GLYCINE AND L-ALANINE AT DIFFERENT TEMPERATURES

\begin{tabular}{|c|c|c|c|c|c|c|c|c|}
\hline \multirow{2}{*}{$\begin{array}{c}* \mathrm{~m}_{\mathrm{D}} \\
\left(\mathrm{mol} \mathrm{kg} \mathrm{kg}^{-1}\right)\end{array}$} & $305.15 \mathrm{~K}$ & $310.15 \mathrm{~K}$ & $315.15 \mathrm{~K}$ & $320.15 \mathrm{~K}$ & $305.15 \mathrm{~K}$ & $310.15 \mathrm{~K}$ & $315.15 \mathrm{~K}$ & $320.15 \mathrm{~K}$ \\
\hline & \multicolumn{4}{|c|}{ Doxycycline hyclate + water } & \multicolumn{4}{|c|}{ Doxycycline hyclate $+0.002 \mathrm{~mol} \mathrm{~kg}^{-1}$ glycine } \\
\hline 0.002 & 227.19 & 252.50 & 267.98 & 294.73 & 176.42 & 188.99 & 202.19 & 226.95 \\
\hline 0.003 & 216.22 & 228.91 & 247.66 & 261.05 & 164.57 & 182.18 & 188.63 & 218.43 \\
\hline 0.004 & 196.73 & 205.19 & 233.98 & 238.06 & 157.66 & 172.55 & 183.51 & 214.61 \\
\hline 0.005 & 189.82 & 192.74 & 219.04 & 219.97 & 150.12 & 167.61 & 177.71 & 205.90 \\
\hline 0.006 & 181.43 & 184.33 & 204.70 & 205.91 & 146.78 & 163.72 & 169.90 & 202.42 \\
\hline 0.007 & 173.89 & 178.33 & 193.48 & 194.46 & 146.14 & 159.38 & 165.00 & 196.74 \\
\hline 0.008 & 167.45 & 173.85 & 185.57 & 189.64 & 144.91 & 157.39 & 159.30 & 192.00 \\
\hline 0.009 & 165.89 & 170.38 & 182.55 & 185.90 & 143.97 & 155.63 & 157.71 & 189.88 \\
\hline \multirow[t]{2}{*}{0.010} & 160.99 & 167.61 & 180.15 & 182.93 & 143.23 & 153.04 & 155.14 & 187.20 \\
\hline & \multicolumn{4}{|c|}{ Doxycycline hyclate $+0.004 \mathrm{~mol} \mathrm{~kg}^{-1}$ glycine } & \multicolumn{4}{|c|}{ Doxycycline hyclate $+0.006 \mathrm{~mol} \mathrm{~kg}^{-1}$ glycine } \\
\hline 0.002 & 189.90 & 202.63 & 219.74 & 227.18 & 191.06 & 208.32 & 218.28 & 234.67 \\
\hline 0.003 & 181.27 & 192.32 & 209.62 & 220.77 & 184.62 & 196.84 & 210.39 & 225.54 \\
\hline 0.004 & 178.58 & 184.15 & 194.61 & 210.82 & 180.91 & 188.06 & 200.40 & 218.28 \\
\hline 0.005 & 172.96 & 177.57 & 188.78 & 201.45 & 173.5 & 184.73 & 192.02 & 210.14 \\
\hline 0.006 & 169.98 & 172.36 & 182.14 & 195.66 & 170.97 & 178.86 & 186.78 & 203.67 \\
\hline 0.007 & 167.99 & 168.65 & 180.84 & 185.25 & 168.44 & 174.29 & 182.06 & 195.49 \\
\hline 0.008 & 165.85 & 165.89 & 177.38 & 180.21 & 166.19 & 172.61 & 176.28 & 189.13 \\
\hline 0.009 & 162.45 & 163.75 & 174.48 & 174.98 & 165.23 & 171.32 & 174.14 & 184.31 \\
\hline \multirow[t]{2}{*}{0.010} & 161.08 & 162.05 & 170.97 & 171.99 & 163.48 & 170.23 & 172.43 & 182.86 \\
\hline & \multicolumn{4}{|c|}{ Doxycycline hyclate $+0.002 \mathrm{~mol} \mathrm{~kg}^{-1} \mathrm{~L}$-alanine } & \multicolumn{4}{|c|}{ Doxycycline hyclate $+0.004 \mathrm{~mol} \mathrm{~kg}^{-1} \mathrm{~L}$-alanine } \\
\hline 0.002 & 225.29 & 243.15 & 263.81 & 284.06 & 229.05 & 248.28 & 264.8 & 284.08 \\
\hline 0.003 & 220.97 & 236.80 & 253.65 & 270.00 & 225.11 & 241.86 & 253.73 & 272.65 \\
\hline 0.004 & 217.19 & 229.43 & 244.85 & 259.1 & 221.17 & 235.29 & 243.95 & 261.93 \\
\hline 0.005 & 213.40 & 223.06 & 237.99 & 249.92 & 217.63 & 228.76 & 236.5 & 250.27 \\
\hline 0.006 & 210.90 & 218.68 & 232.60 & 243.30 & 214.97 & 223.59 & 229.37 & 242.02 \\
\hline 0.007 & 209.14 & 215.56 & 228.77 & 236.88 & 213.08 & 219.92 & 224.29 & 236.14 \\
\hline 0.008 & 207.83 & 213.25 & 225.92 & 232.83 & 211.69 & 217.19 & 220.51 & 231.76 \\
\hline 0.009 & 206.84 & 211.47 & 223.72 & 229.700 & 210.62 & 215.08 & 217.58 & 228.37 \\
\hline \multirow[t]{2}{*}{0.010} & 206.05 & 210.05 & 221.98 & 227.22 & 209.78 & 213.41 & 215.26 & 225.67 \\
\hline & \multicolumn{4}{|c|}{ Doxycycline hyclate $+0.006 \mathrm{~mol} \mathrm{~kg}^{-1} \mathrm{~L}$-alanine } & & & & \\
\hline 0.002 & 240.14 & 259.64 & 275.12 & 296.58 & & & & \\
\hline 0.003 & 233.31 & 248.46 & 262.37 & 275.45 & & & & \\
\hline 0.004 & 227.93 & 240.21 & 249.00 & 261.64 & & & & \\
\hline 0.005 & 223.12 & 232.07 & 239.90 & 250.39 & & & & \\
\hline 0.006 & 219.60 & 227.84 & 234.75 & 240.00 & & & & \\
\hline 0.007 & 217.11 & 224.85 & 227.81 & 235.43 & & & & \\
\hline 0.008 & 215.26 & 222.63 & 225.62 & 230.75 & & & & \\
\hline 0.009 & 213.84 & 220.92 & 223.94 & 229.46 & & & & \\
\hline 0.010 & 212.72 & 219.56 & 220.61 & 228.45 & & & & \\
\hline
\end{tabular}

$* \mathrm{~m}_{\mathrm{D}}$ is the molality of doxycycline hyclate in water and in different concentrations of glycine and L-alanine. 
TABLE-6

VALUES OF LIMITING MOLAR CONDUCTANCE $\left(\Lambda_{\mathrm{m}}^{\circ}\right)$ AND WALDEN PRODUCT $\left(\Lambda_{\mathrm{m}}^{\circ} \eta_{\mathrm{o}}\right)$ FOR DOXYCYCLINE HYCLATE IN WATER, AQUEOUS GLYCINE AND L-ALANINE AT DIFFERENT TEMPERATURES

\begin{tabular}{|c|c|c|c|c|c|c|c|c|}
\hline \multirow{2}{*}{$\begin{array}{c}* \mathrm{~m}_{\mathrm{A}} \\
\left(\mathrm{mol} \mathrm{kg}^{-1}\right)\end{array}$} & \multicolumn{4}{|c|}{ 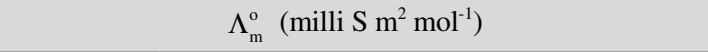 } & \multicolumn{4}{|c|}{$\Lambda_{\mathrm{m}}^{\mathrm{o}} \eta_{\mathrm{o}}\left(? \mathrm{~S} \mathrm{~m}^{2} \mathrm{~mol}^{-1} \mathrm{~Pa} \mathrm{~s}\right)$} \\
\hline & $305.15 \mathrm{~K}$ & $310.15 \mathrm{~K}$ & $315.15 \mathrm{~K}$ & $320.15 \mathrm{~K}$ & $305.15 \mathrm{~K}$ & $310.15 \mathrm{~K}$ & $315.15 \mathrm{~K}$ & $320.15 \mathrm{~K}$ \\
\hline \multicolumn{9}{|c|}{ Doxycycline hyclate + water } \\
\hline 0.000 & 279.00 & 308.28 & 338.71 & 370.90 & 0.2133 & 0.2134 & 0.2135 & 0.2138 \\
\hline \multicolumn{9}{|c|}{ Doxycycline hyclate + aqueous glycine } \\
\hline 0.002 & 195.90 & 216.20 & 237.40 & 259.50 & 0.1509 & 0.1510 & 0.1518 & 0.1521 \\
\hline 0.004 & 210.20 & 232.10 & 253.90 & 277.30 & 0.1624 & 0.1627 & 0.1629 & 0.1631 \\
\hline 0.006 & 212.10 & 234.20 & 256.10 & 279.90 & 0.1644 & 0.1646 & 0.1649 & 0.1649 \\
\hline \multicolumn{9}{|c|}{ Doxycycline hyclate + aqueous L-alanine } \\
\hline 0.002 & 239.90 & 269.20 & 294.60 & 326.20 & 0.1854 & 0.1886 & 0.1889 & 0.1918 \\
\hline 0.004 & 244.10 & 276.80 & 302.90 & 331.10 & 0.1892 & 0.1946 & 0.1948 & 0.1953 \\
\hline 0.006 & 260.30 & 287.30 & 314.40 & 342.90 & 0.2024 & 0.2026 & 0.2028 & 0.2030 \\
\hline
\end{tabular}

In the above equation $\Lambda_{\mathrm{m}}^{\mathrm{o}}$ is the limiting molar conductance, $\mathrm{K}$ is constant and $\mathrm{C}$ is molar concentration.

Walden product $\left(\Lambda_{\mathrm{m}}^{\mathrm{o}} \eta_{\mathrm{o}}\right)$ has been calculated using the limiting molar conductance $\Lambda_{\mathrm{m}}^{\mathrm{o}}$. The related data is shown in Table-6. The variation of Walden product with temperature i.e. $\mathrm{d} \Lambda_{\mathrm{m}}^{\mathrm{o}} \eta_{\mathrm{o}} / \mathrm{dT}$ reveals important information about structure maker and breaker behaviour of solute. The positive values of $\mathrm{d} \Lambda_{\mathrm{m}}^{\mathrm{o}} \eta_{\mathrm{o}} / \mathrm{dT}$ for doxycycline hyclate in different solvent systems suggest structure maker nature of doxycycline hyclate in different solvent systems which have been supported by the conclusions drawn from the viscosity parameters.

\section{Conclusion}

The viscometric and conductance measurement of doxycycline hyclate in water, aqueous glycine and aqueous L-alanine solutions has been carried out and results are analyzed in terms of interactions present in the binary as well as in ternary system. The positive viscosity B-coefficient and $\Delta_{\mathrm{tr}} \mathrm{B}$ values found to follow the trend L-alanine $>$ glycine $>$ water which indicates more productive hydrophilic-ionic interactions in aqueous amino acid solutions than in water which may be due to the effective hydrophilic-ionic interaction between zwitter ionic group of glycine/L-alanine and charged groups of drug. The negative magnitude of $\mathrm{dB} / \mathrm{dT}$ indicates structure making behaviour of doxycycline hyclate in water as well as in aqueous solutions of glycine/L-alanine. The higher values of $\Delta \mu_{2}^{0^{*}}$ than $\Delta \mu_{1}^{\mathrm{O}^{*}}$ indicate difficulty in the formation of transition state which indicates strong intermolecular interactions in the ground state than in transition state. The positive magnitude of $\mathrm{T} \Delta \mathrm{S}_{2}^{0^{*}}$ and $\Delta \mathrm{H}_{2}^{\mathrm{o}^{*}}$ indicates cleavage of intermolecular bonds in the transition state which means formation of transition state is highly unfavourable. The positive magnitude of $\mathrm{d} \Lambda_{\mathrm{m}}^{\mathrm{o}} \eta_{\mathrm{o}} / \mathrm{dT}$ further support the fact that doxycycline hyclate behaves as structure maker in different solvent systems.

\section{ACKNOWLEDGEMENTS}

One of the authors, Poonam Thakur is grateful to CSIR New Delhi, India for the financial support (sanction letter no. 09/237(0153)/2014-EMR-I).

\section{CONFLICT OF INTEREST}

The authors declare that there is no conflict of interests regarding the publication of this article.

\section{REFERENCES}

1. G.A. Petsko and J.R. Yates III, Curr. Protoc. Bioinform., 36, 8.1.1 (2011); https://doi.org/10.1002/0471250953.bi0801s36.

2. T.C. Ramalho and E.F.F. Da Cunha, J. Biomol. Struct. Dyn., 28, 645 (2011); https://doi.org/10.1080/073911011010524975.

3. A. Ali, R. Patel and S. Khan and V. Bhushan, Z. Naturforsch., 64, 758 (2009);

https://doi.org/10.1515/zna-2009-1113.

4. A. Ali, S. Sabir, A.K. Nain, S. Hyder, S. Ahmad, M. Tariq and R. Patel, J. Chin. Chem. Soc., 54, 659 (2007); https://doi.org/10.1002/jccs.200700094.

5. K. Zhuo, Q. Liu, Y. Wang, Q. Ren and J. Wang, J. Chem. Eng. Data, 51, 919 (2006); https://doi.org/10.1021/je050412t.

6. U.B. Kadam, A.P. Hiray, A.B. Sawant and M. Hasan, J. Chem. Eng. Data, 51, 60 (2006);

https://doi.org/10.1021/je050169y.

7. S.A. Shaikh, S.R. Ahmed and B. Jayaram, Arch. Biochem. Biophys., 429, 81 (2004);

https://doi.org/10.1016/j.abb.2004.05.019.

8. S. Chakravarty, V.S. Yadava, V. Kumar and K.K. Kannan, J. Biosci.,, 8, 491 (1985);

https://doi.org/10.1007/BF02704000.

9. T.S. Banipal, J. Kaur, P.K. Banipal and K. Singh, J. Chem. Eng. Data, 53, 1803 (2008);

https://doi.org/10.1021/je8001464.

10. A. Pal and S. Kumar, J. Chem. Thermodyn., 37, 1085 (2005); https://doi.org/10.1016/j.jct.2004.12.015.

11. A.K. Nain and D. Chand, J. Chem. Thermodyn., 41, 243 (2009); https://doi.org/10.1016/j.jct.2008.09.008.

12. D.P. Kharakoz, J. Phys. Chem., 95, 5634 (1991); https://doi.org/10.1021/j100167a049.

13. G.R. Hedwig and H. Hoiland, J. Chem. Thermodyn., 25, 349 (1993); https://doi.org/10.1006/jcht.1993.1035.

14. M. Sahayam and G.R. Hedwig, J. Chem. Thermodyn., 26, 361 (1994); https://doi.org/10.1006/jcht.1994.1045.

15. R. Bhat and J.C. Ahluwalia, J. Phys. Chem., 89, 1099 (1985); https://doi.org/10.1021/j100253a011.

16. T.V. Chalikian, A.P. Sarvazyan and K.J. Breslauer, J. Phys. Chem., 97, 13017 (1993); https://doi.org/10.1021/j100151a061.

17. T.V. Chalikian, A.P. Sarvazyan and K.J. Breslauer, J. Biophys. Chem., 51, 89 (1994); https://doi.org/10.1016/0301-4622(94)85007-0.

18. B. Sinha, B.K. Sarkar and M.N. Roy, J. Chem. Thermodyn., 40, 394 (2008); https://doi.org/10.1016/j.jct.2007.09.012.

19. M.J. Iqbal and M. Siddiquah, J. Braz. Chem. Soc., 17, 851 (2006); https://doi.org/10.1590/S0103-50532006000500006.

20. B. Hess and N.F.A. van der Vegt, J. Phys. Chem. B, 110, 17616 (2006); https://doi.org/10.1021/jp0641029. 
21. M.S. Bakshi, J. Phys. Chem. C, 115, 13947 (2011); https://doi.org/10.1021/jp202454k.

22. H. Kumar and K. Kaur, Thermochim. Acta, 551, 40 (2013); https://doi.org/10.1016/j.tca.2012.10.018.

23. H. Kumar and K. Kaur, J. Mol. Liq., 173, 130 (2012); https://doi.org/10.1016/j.molliq.2012.07.008.

24. S. Chauhan, K. Singh, K. Kumar, S.C. Neelakantan and G. Kumar, J. Chem. Eng. Data, 61, 788 (2016); https://doi.org/10.1021/acs.jced.5b00549.

25. S. Kant, A. Kumar and S. Kumar, J. Mol. Liq., 150, 39 (2009); https://doi.org/10.1016/i.molliq.2009.09.010.

26. B. Sinha, V.K. Dakua and M.N. Roy, J. Chem. Eng. Data, 52, 1768 (2007); https://doi.org/10.1021/je7001418.

27. N.G. Tsierkezos and I.E. Molinou, J. Chem. Eng. Data, 43, 989 (1998); https://doi.org/10.1021/je9800914.

28. S. Chauhan, P. Chaudhary, K. Sharma, K. Kumar and Kiran, Chem. Pap., 67, 1442 (2013); https://doi.org/10.2478/s11696-013-0404-y.

29. K. Sharma and S. Chauhan, Thermochim. Acta, 578, 15 (2014); https://doi.org/10.1016/j.tca.2013.12.021.

30. S.S. Dhondge, S.P. Zodape and D.V. Parwate, J. Chem. Thermodyn., 48, 207 (2012); https://doi.org/10.1016/j.jct.2011.12.022.
31. K. Kaur and H. Kumar, J. Mol. Liq., 177, 49 (2013); https://doi.org/10.1016/i.molliq.2012.09.016.

32. G. Jones and M.J. Dole, J. Am. Chem. Soc., 51, 2950 (1929); https://doi.org/10.1021/ja01385a012.

33. S. Chauhan, K. Kumar, M.S. Chauhan, D.S. Rana and A. Umar, Adv. Sci. Eng. Med., 5, 991 (2013); https://doi.org/10.1166/asem.2013.1362.

34. D. Feakins, D.J. Freemantle and K.G. Lawrence, J. Chem. Soc., Faraday Trans., 70, 795 (1974); https://doi.org/10.1039/f19747000795.

35. K. Kumar, B.S. Patial and S. Chauhan, J. Chem. Eng. Data, 60, 47 (2015); https://doi.org/10.1021/je500647a.

36. S. Chauhan, L. Pathania, K. Sharma and G. Kumar, J. Mol. Liq., 212, 656 (2015); https://doi.org/10.1016/j.molliq.2015.09.042.

37. S. Glasstone, K.J. Laidler and H. Eyring, The Theory of Rate Processes: The Kinetics of Chemical Reactions, Viscosity, Diffusion and Electrochemical Phenomena, McGraw Hill: New York (1941).

38. D. Feakins, F.M. Bates, W.E. Waghorne and K.G. Lawrence, J. Chem. Soc., Faraday Trans., 89, 3381 (1993); https://doi.org/10.1039/FT9938903381.

39. A. Pal and S. Kumar, J. Mol. Liq., 109, 23 (2004); https://doi.org/10.1016/..molliq.2003.07.003. 